\title{
Short Communication: Drying methods and diversity of contaminant fungi on coffee beans in South Ogan Komering Ulu District, South Sumatra, Indonesia
}

\author{
DELI LILIA ${ }^{1}$, NURHAYATI DAMIRI ${ }^{1,2, \vartheta}$, M. ZULKARNAIN ${ }^{1}$, MULAWARMAN ${ }^{1,2}$ \\ ${ }^{1}$ Doctoral Program of Environmental Science, Graduate School, Universitas Sriwijaya. Jl. Padang Selasa No. 524, Bukit Besar, Palembang 30139, South \\ Sumatra, Indonesia. Tel.: +62-711-352132, Fax.: +62-711-317202, `email: nurhayati@ fp.unsri.ac.id \\ ${ }^{2}$ Department of Pest and Disease, Faculty of Agriculture, Universitas Sriwijaya. Jl. Raya Palembang-Prabumulih Km. 32, Indralaya, Ogan Ilir 30662 , \\ South Sumatra, Indonesian
}

Manuscript received: 8 December 2020. Revision accepted: 25 January 2021

\begin{abstract}
Lilia D, Damiri N, Zulkarnain M, Mulawarman. 2021. Short Communication: Drying methods and diversity of contaminant fungi on coffee beans in South Ogan Komering Ulu District, South Sumatra, Indonesia. Biodiversitas 22: 1037-1042. South Ogan Komering Ulu District is a Robusta coffee-producing area in South Sumatra. The purpose of this research was to determine the effectiveness of two drying methods on reducing the moisture content of coffee beans by comparing beans dried on tarpaulin and on asphalt roads. The study also assessed the diversity and percentage of fungal contaminants found in coffee beans from each drying method (including OTA-producing fungi). Data was obtained from May until July 2020 from surveys, interviews and samples collected from 30 farmers drying on tarpaulin and 30 farmers drying on the asphalt. The results showed that the moisture content was higher after drying on tarpaulin $(13.97 \% \pm 0.55)$ than on the asphalt road $(11.68 \% \pm 0.40)$. Furthermore, 13 different types of fungi were found for the coffee beans drying on the tarpaulin and 10 types of fungi for those drying on asphalt. In the two methods of drying, it was found that two types of fungi namely Aspergillus niger and Aspergillus ochraceus were potential of producing ochratoxin A (OTA). At the drying on tarpaulin was found mix of more than 93.3\% A.niger and A. ochraceus, meanwhile at the drying on asphalt were found mix of more than $90 \%$ A.niger and A.ochraceus respectively.
\end{abstract}

Keywords: Coffee beans, contaminant fungi, diversity, drying method

\section{INTRODUCTION}

Indonesia is the fourth largest coffee producer in the world. Indonesia's coffee production reached 565.08 tons in 2018 , which was $5.53 \%$ of the world's total coffee production (International Coffee Organization 2019). The quality of coffee is greatly affected by post-harvest processing, including traditional drying methods. It requires bright sunlight and large area for drying. This is greatly influenced by daily weather conditions, if the weather is undesirable, the coffee beans take longer to dry. Machines can be used to speed the drying process, but this can cause wrinkling to the skin of the coffee beans, which negatively affects their quality. Because of this, farmers in tropical and subtropical regions use traditional methods of drying. Furthermore, the presence of dust and dirt contamination also affects coffee quality and production, as well as farmers' income (Ghosh and Venkatachalapathy 2014; Djossou et al. 2015).

Post-harvest handling, operations can cause damage to coffee beans. The incomplete drying may lead to the xerophilic and toxigenic fungal contamination. Varga et al. (2011) and Bui-klimke and Wu (2015) reported that in tropical areas, Ochratoxin A (OTA) was produced by Aspergillus carbonarius, A. Niger, and A. ochraceus. Black Aspergilli is the dominant group of Aspergillus contaminating Robusta coffee in Thailand (Noonim et al
2008). In sub-tropical areas, OTA was produced by Penicillium verrucosum. Fungi and the subsequent OTA in coffee is problematic, and can cause liver cancer and degeneration, fever, brain swelling, kidney failure, and neurological disorders (Duris et al. 2010; Reichert et al. 2017; Leitao 2019).

South Ogan Komering Ulu (OKU Selatan) District is one of the Robusta coffee producing areas in the province of South Sumatra, with an area of 70,799 hectares spread over 11 sub-districts. In this region, there are two methods of drying coffee beans, namely drying on tarpaulin and drying on asphalt roads that are commonly used by farmers. Drying on asphalt is no longer allowed because of regulations put in place by the local government. In some places, however, this method is still used by farmers because it accelerates the drying process, therefore, the coffee beans can be sent to market sooner. Considering that the drying process in the District is still traditional, especially in the sub-district of BPR Ranau Tengah (using tarpaulin) and Buay Sandang Aji (using asphalt roads), research has been carried out to determine the effect of drying methods on the diversity of contaminant fungi found in coffee beans. Considering that there has been no previous research on post-harvest processing, especially the drying process, this research can be one of the benchmarks for improving coffee postharvest. 


\section{MATERIALS AND METHODS}

\section{Study area}

South Ogan Komering Ulu (OKU Selatan) District is one of the Robusta coffee producing areas in the Province of South Sumatra, Indonesia with an area of 70,799 hectares spread over 11 sub-districts (Figure 1).

\section{Procedures}

This research was conducted in the Microbiology Laboratory at the Faculty of Mathematics and Natural Sciences, Sriwijaya University, Inderalaya, Indonesia and community coffee plantations in Buay Pematang Ribu Ranau Tengah (BPR Ranau Tengah) and Buay Sandang Aji Sub-district of in South Ogan Komering Ulu District, South Sumatra Province, Indonesia from May until July 2020. Sampling was carried out by a purposive method from 30 coffee farmers at 11 villages of BPR Ranau Tengah Subdistrict (drying on tarpaulin) and 30 coffee farmers from 12 villages in Buay Sandang Aji Subdistrict (drying on the asphalt road). A sampling of coffee beans from each farmer was taken then observed and examined in the laboratory to check moisture content, identify fungi, and determine the percentage of fungal attack.

Each sample consisted of 1000 grams of coffee beans randomly collected from each coffee farmer. Samples were packed in airtight bags to avoid changes in coffee during transport between the sampling locations and the laboratory in Inderalaya, Indonesia. Then each sample was divided homogeneously using the Sample Divider and examined.

\section{Moisture analysis (SNI 01-2907:2008)}

A clean porcelain dish was dried in a drying oven at $105^{\circ} \mathrm{C}$ for 1 hour with the lid removed. Then the dish was removed and cooled in a desiccator with the lid removed for another 1 hour. After cooling, the porcelain dishes were weighed in a closed environment. Next, two grams of coffee were placed on the porcelain dish and dried in an oven at $80^{\circ} \mathrm{C}$ for 8 hours, or until the weight remains constant. The porcelain cup was then closed by using pliers and cooled in a desiccator for 30 minutes with the cap removed. After cooling, the porcelain dish was closed again and weighed. The moisture content was determined by calculating the difference between the weight of the coffee sample before and after drying in the oven. The moisture content analysis test was carried out twice.

$$
\begin{aligned}
& \text { Calculation: Moisture Content }=\frac{\mathrm{W} 1-\mathrm{W} 2}{\mathrm{~W} 1-\mathrm{W} 0} \times 100 \% \\
& \text { Where; } \\
& \text { W0 : The weight of the dish and lid(gram) } \\
& \text { W1: Initial sample weight }(\text { gram }) \\
& \text { W2: Final sample weight after drying(gram) }
\end{aligned}
$$

\section{Analysis of fungi types in coffee beans}

The analysis was performed by using direct plating methods as described by Samson et al. (2004). Coffee beans from each sample were disinfected with $1 \%$ sodium hypochlorite for one minute and rinsed with sterile distilled water for 1 minute, with 2 replications. They were then dried in a Petri dish covered with 2 sheets of sterile filter paper. Then, a total of 10 beans were placed in a Petri dish ( $9 \mathrm{~cm}$ in diameter) containing a PDA medium with $0.01 \%$ chloramphenicol. The beans were inoculated when the medium was frozen and then incubated at $28^{\circ} \mathrm{C}$ temperature until there was fungal growth on the medium (4-5 days). The beans were observed macroscopically by paying attention to the characteristics of each fungus. Furthermore, the fungal isolates were grown on MEA (Malt Extract Agar) medium and observed microscopically. Identification was carried out by using key fungal identification tables or matching the descriptions by Houbraken et al. (2012), Gautam and Bhadaurai (2012) and Samson et al. (2014).
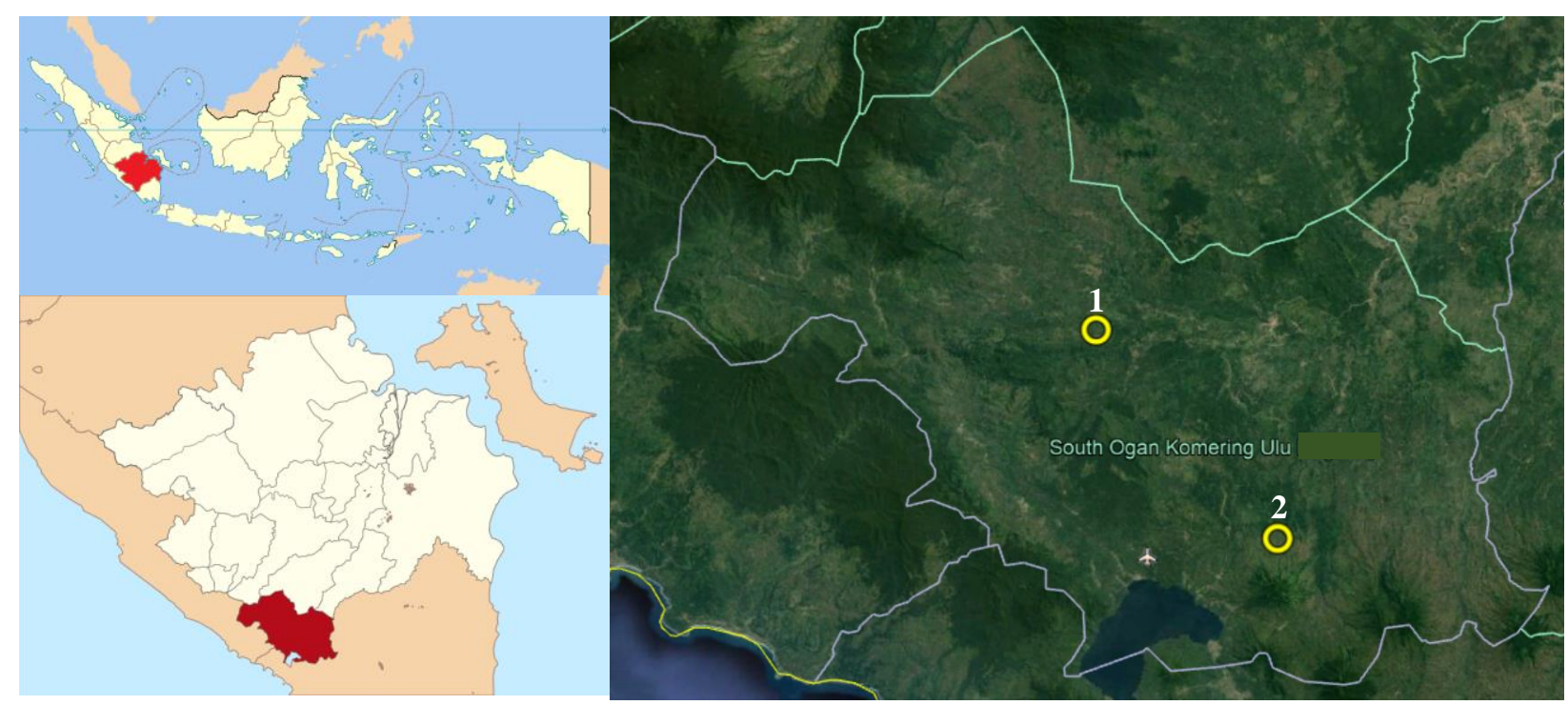

Figure 1. Location of the research in South Ogan Komering Ulu District, South Sumatra Province, Indonesia, i.e., 1. Buay Sandang Aji (4³2'24.3”'S, 103'52'46.6”E), 2. BPR Ranau Tengah (446’02.8” S,1040.'36.8”W) 


\section{Fungi percentage} 1980):

The percentage of fungi was calculated by (Mehrotra

Percentage of fungi $=\frac{\begin{array}{c}\text { Number of fungus infested } \\ \text { coffee beans }\end{array}}{\text { Number of coffee beans }} \times 100 \%$

\section{Data analysis}

Moisture content was analyzed using the one-way nonparametric Wilcoxon test, followed by the Mann-Whitney test. The percentage of fungi was analyzed using the Independent $\mathrm{T}$-test if the data were normal and homogeneous. If the test data were not normal, a Kruskal Wallis test was used.

\section{RESULTS AND DISCUSSION}

\section{Moisture content on coffee beans}

The results of moisture content analysis of coffee beans before and after drying on tarpaulin are presented in Table 1. It was observed that drying of the coffee beans using a tarpaulin, has significant difference in moisture content ( $\mathrm{p}$ value 0.000). Likewise, the results of moisture content analysis of coffee beans before and after drying on asphalt are presented in Table 2, which also showed a significant difference before and after drying on asphalt ( $p$-value 0.000).

The moisture content in fresh coffee beans before drying is quite high, at $62.26 \% \pm 0.76 \%$. After drying on the asphalt road, moisture was $11.68 \% \pm 0.40 \%$ (Table 2) while drying on a tarpaulin, it was $13.97 \% \pm 0.55 \%$ (Table $1)$. This indicates that the water content in the coffee beans after drying is higher on tarpaulin than on asphalt roads. When drying, the average temperature on the tarpaulin was $31^{\circ} \mathrm{C}$ with an average relative humidity of $45 \%$, while the average temperature of drying on the asphalt road was $34.3^{\circ} \mathrm{C}$ with an average relative humidity of $56 \%$.

The drying process, influences the susceptibility of fungi to penetrate the seeds, becoming a risk for physical quality accompanied by defects in the flavor (Ribeiro et al. 2011). Furthermore, all stages from the pre-harvest, postharvest, preparation, transportation and storage have a risk to be contaminated with microorganisms that can also damage the coffee beans (Rezende et al. 2013). The comparison of the moisture content of coffee beans dried directly on the asphalt with those dried on a tarpaulin is presented in Table 3.

A Mann-Whitney test showed that there is a significant difference between drying on asphalt and on tarpaulin (pvalue 0.000 ). The moisture content of drying on the asphalt was $11.68 \pm 0.40 \%$ as compared to those drying on the tarpaulin that was $13.97 \pm 0.55 \%$. Consequently, relatively high moisture content causes the growth of fungi on the tarpaulin. According to Neto et al. (2017) and Bradford et al. (2018), the growth of molds or fungi requires a moisture content of at least $13 \%$ to allow the enzyme activation process. Meanwhile, the $11 \%$ moisture content of the coffee beans dried on asphalt is less likely for the growth of fungi. However, coffee beans should only be dried to 11$12 \%$. If the moisture content of coffee beans is more than $13 \%$, it can be susceptible to be attacked by microorganisms, the formation of mycotoxins, and discoloration. Meanwhile, if it is less than the SNI (Indonesian National Standard) $12.50 \%$, it will cause the coffee beans to break easily, i.e. decreasing quality.

Table 1. Moisture content of coffee beans before and after drying on Tarpaulin

\begin{tabular}{|c|c|c|c|}
\hline \multirow{2}{*}{ Variable moisture content of coffee beans } & \multicolumn{2}{|c|}{ Moisture content (\%) } & \multirow[t]{2}{*}{ p-value } \\
\hline & Before drying & After drying & \\
\hline Mean \pm SD & $62.26 \pm 0.76$ & $13.97 \pm 0.55$ & \\
\hline Median (Min-Max) & $63.13(62.30-64.34)$ & $11.76(10.56-12.10)$ & 0.000 \\
\hline
\end{tabular}

Table 2. Moisture content of coffee beans before and after drying on Asphalt

\begin{tabular}{lccc}
\hline \multirow{2}{*}{ Variable moisture content of coffee beans } & \multicolumn{2}{c}{ Moisture content } & p-value \\
\cline { 2 - 3 } & Before drying & After drying & $11.68 \pm 0.40$ \\
Mean \pm SD & $62.26 \pm 0.76$ & $11.73(10.56-12.10)$ & 0.000 \\
Median (Mi-Max) & $63.13(62.30-64.34)$ & &
\end{tabular}

Table 3. Comparison of the Moisture Content of Coffee Beans by Drying Method

\begin{tabular}{lccc}
\hline \multirow{2}{*}{ Variable moisture content of coffee beans } & \multicolumn{2}{c}{ Drying methods } & \multirow{2}{*}{ p-value } \\
\cline { 2 - 3 } & Asphalt road & Tarpaulin & $13.97 \pm 0.55$ \\
Mean \pm SD & $11.68 \pm 0.40$ & $14.11(11.97-14.30)$ & 0.000 \\
Median (Min-Max) & $11.73(10.56-12.10)$ &
\end{tabular}




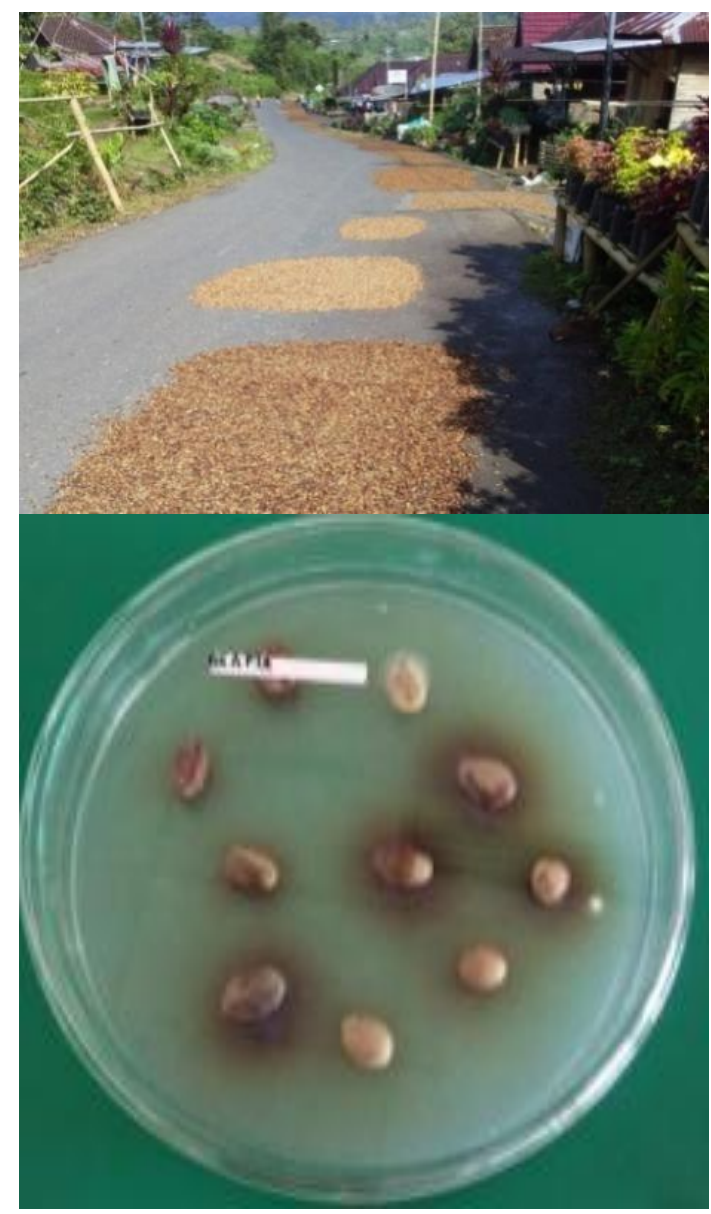

A

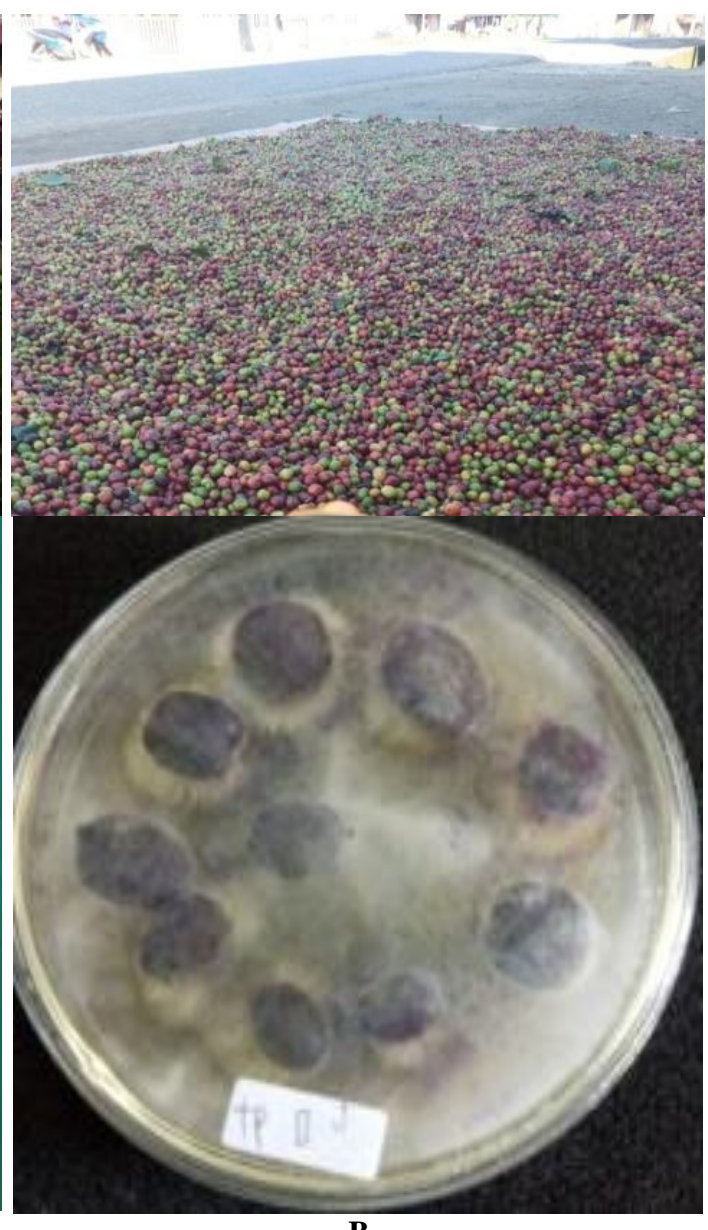

B

Figure 1. A. Coffee beans dried on asphalt road and tested on PDA. B. Coffee beans dried on tarpaulin and tested on PDA

\section{Diversity of fungi contaminating coffee beans}

From the results, it was found that 13 types of fungi were contaminating coffee beans dried on the tarpaulin. Meanwhile, 10 fungi types were found on coffee dried on the asphalt road (Figure 1 and Table 4).

Table 4 shows that it was found in greater quantities of fungi after tarpaulin drying than asphalt drying, namely $A$. niger, A, ochraceus, A. flavus, A. fumigatus and Penicillium notatum. Meanwhile, A wentii, Mucor javanicus and Rhizopus arrhizus were more commonly found after drying on asphalt than on the tarpaulin. Fusarium oxysporum (46.6\%), F. semitectum (33.3\%), F. acuminatum (26.6\%), and Lasiodiplodia theobromae $(86.6 \%)$ were only found on tarpaulin dried beans while Eurotium chevaleri $(30 \%)$ were only found on asphalt dried beans. The percentage of $R$. oryzae (20\%) was found equal in both methods of drying.

The genus Aspergillus is one of the dominating genus of fungi found infecting coffee beans in both drying methods. Aspergillus is one of the few microbes that are widespread and abundant in nature. This type of fungus is also a common contaminant on various substrates in the tropics and subtropics. The Aspergillus niger was found dominant in both methods of drying, which showed its cosmopolitan properties, and moist coffee beans being a suitable substrate for growth. This species can easily spread as its fungal spores are transported by the wind (Samson et al. 2014; Nganou et al. 2014; Alvindia and Guzman 2016).

Table 4. Variety and percentage of fungi found in coffee beans dried on asphalt and tarpaulin

\begin{tabular}{lcc}
\hline \multirow{2}{*}{ Fungi species } & \multicolumn{2}{c}{ Number $(\%)$ of coffee samples infected } \\
\cline { 2 - 3 } & Asphalt & Tarpaulin \\
\hline A. niger & $27(90 \%)$ & $28(93.3 \%)$ \\
A. ochraceus & $5(16.6 \%)$ & $7(23.3 \%)$ \\
A. flavus & $16(53.3 \%)$ & $25(83.3 \%)$ \\
A. wentii & $11(36.7 \%)$ & $5(16.6 \%)$ \\
A. fumigatus & $17(56.7 \%)$ & $25(83.3 \%)$ \\
Mucor javanicus & $14(46.6 \%)$ & $12(40 \%)$ \\
Rhizopus arrhizus & $10(33.3 \%)$ & $8(26.6 \%)$ \\
R. oryzae & $6(20 \%)$ & $6(20 \%)$ \\
Penicillium notatum & $8(26.6 \%)$ & $10(33.3 \%)$ \\
Endomycetes fibuliger & $9(30 \%)$ & - \\
F. oxysporum & - & $14(46.6 \%)$ \\
F. semitectum & - & $10(33.3 \%)$ \\
F. acuminatum & - & $8(26.6 \%)$ \\
L. theobromae & - & $26(86.6 \%)$ \\
\hline
\end{tabular}


Table 5. The analysis results on the percentage of fungi types on asphalt and tarpaulin drying

\begin{tabular}{lclc}
\hline \multirow{2}{*}{ Fungi species } & \multicolumn{2}{c}{ Mean \pm SD } & \multirow{2}{*}{ p value } \\
\cline { 2 - 3 } & Asphalt & Tarpaulin & \\
\hline A. niger & $21.36 \pm 8.41$ & $43.36 \pm 23.00$ & 0.000 \\
A. ochraceus & $0.50 \pm 1.71$ & $1.16 \pm 2.66$ & 0.446 \\
A. flavus & $3.53 \pm 3.75$ & $3.16 \pm 3.51$ & 0.717 \\
A. wentii & $0.50 \pm 0.82$ & $0.63 \pm 2.51$ & 0.028 \\
A. fumigatus & $5.30 \pm 7.05$ & $4.33 \pm 11.32$ & 0.487 \\
F. oxysporum & $0.00 \pm 0.00$ & $0.20 \pm 0.40$ & 0.010 \\
F. semitectum & $0.00 \pm 0.00$ & $0.20 \pm 0.40$ & 0.010 \\
F. acuminatum & $0.00 \pm 0.00$ & $0.16 \pm 0.46$ & 0.040 \\
L. theobromae & $0.00 \pm 0.00$ & $3.46 \pm 3.73$ & 0.441 \\
Mucor javanicus & $0.46 \pm 0.50$ & $0.43 \pm 0.81$ & 0.280 \\
Rhizopus arrhizus & $0.36 \pm 0.49$ & $0,20 \pm 0.55$ & 0.065 \\
R. oryzae & $0.40 \pm 0.81$ & $0.20 \pm 0.55$ & 0.411 \\
Penicillium notatum & $0.50 \pm 0.90$ & $1.43 \pm 4.96$ & 0.719 \\
Eurotium chevalieri & $0.39 \pm 0.46$ & $0.00 \pm 0.00$ & 0.001 \\
\hline . & & & \\
\hline
\end{tabular}

Note: Mann Whitney Test $\rho=0.05$

Most of the fungi types found in coffee beans are introduced postharvest. Penicillium is one of the postharvest fungi found in both drying methods. Furthermore, Lasiodiplodia theobromae and Fusarium spp. were also isolated. These usually attack coffee beans before the harvest while they are still in the field but are still found in coffee beans after drying. This is due to the high moisture content of the coffee beans. Pre-harvest fungi that have hydrophilic properties can still grow even after post- harvest stages. Meanwhile, xerophilic fungi, such as Eurotium chevalieri found only in beans dried on asphalt due to the low moisture content (Table 2). The analysis results of the percentage of fungi diversity in each drying method are presented in Table 5.

Table 5 shows that there is an average difference between $A$. niger (p-value 0.000 ) and A. wentii (p-value 0.028 ) between asphalt and tarpaulin drying. While for other fungi, there is no average difference between asphalt and tarpaulin drying, but fungi diversity is greater in tarpaulin drying. This is because there are contaminants obtained from the tarpaulin itself. Most coffee farmers use tarpaulin that has never been washed. The tarpaulin exposed to water when it is raining and slowing the process of the coffee beans drying. Fungal contamination in the natural or dry process according to research (Noonim et al. 2008) is strongly influenced by the processing method. The drying duration, cleanliness, and environmental conditions are closely related to the number of fungi and the production of mycotoxins

From the results of fungi identification, the two drying methods produced two types of fungi that have the potential to produce OTA, namely $A$. niger and $A$. ochraceus. Leitao (2019) and Taniwaki et al. (2019) stated that the occurrence of OTA contamination in coffee beans can be influenced by several factors, including climate, storage time and transportation conditions, as well as the system used (wet, mechanical or dry processes), where the conventional drying process is the most vulnerable.

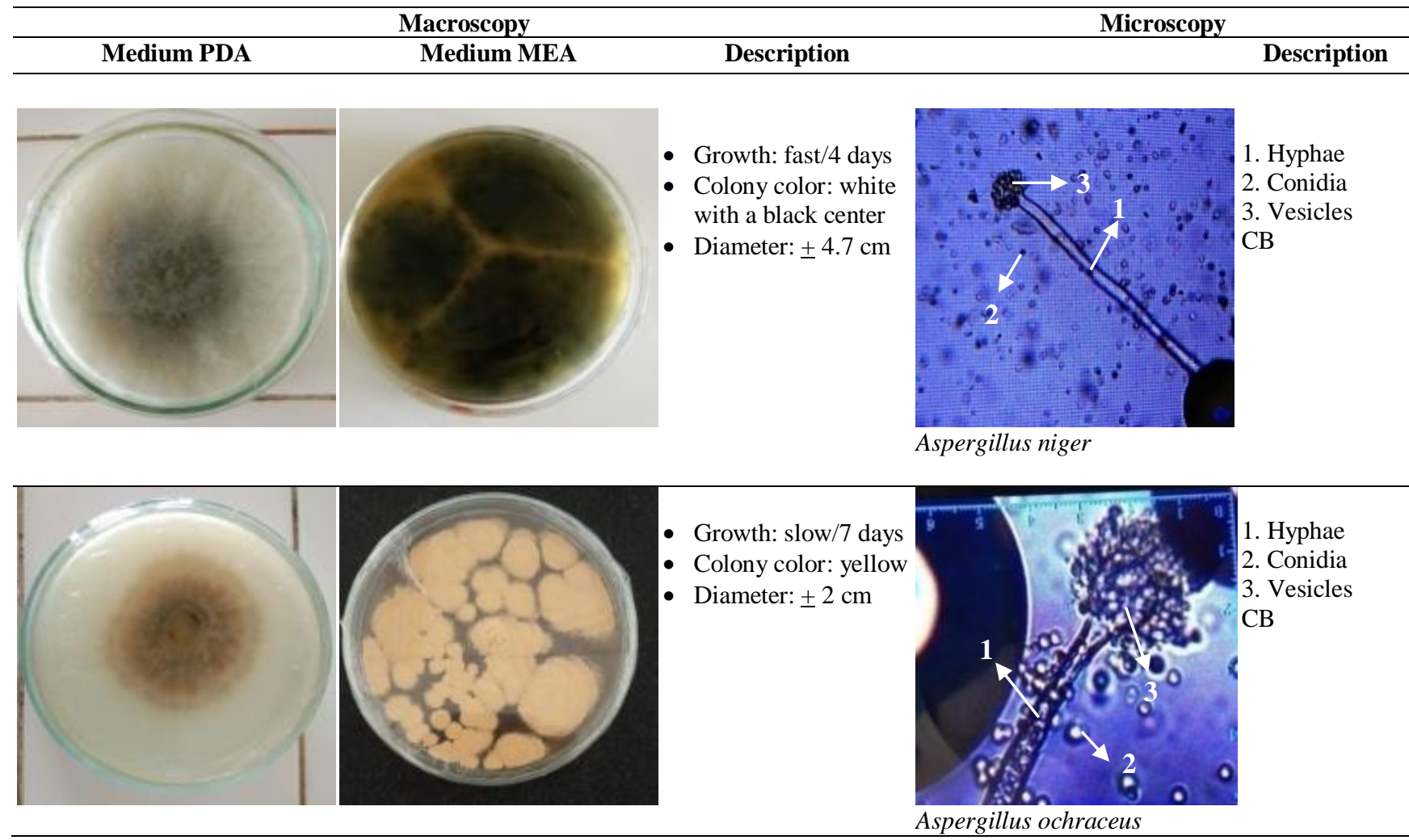

Figure 2. Macroscopic and microscopic characteristics of fungi with the potential to produce ochratoxin A in coffee beans 
In research conducted by Djossou et al. (2015) using PDA media it was found that $97 \%$ of coffee beans were contaminated with fungi, of which $52 \%$ contaminated with the Aspergillus spp. Meanwhile, in the research by (Noonim et al. (2008) on coffee bean samples from Thailand it was found that $77.5 \%$ of beans had contamination of Aspergillus circumdatti, and $75 \%$ of $A$. niger. Whereas, sample of coffee beans in Cameroon, contained A. niger as much as $35-40 \%, A$. carbonarius $15-$ $30 \%$, and A. ochraceus 2-7\% (Nganoe et al. 2014). In research on coffee bean samples in the Philippines, it was found that $90-100 \%$ attacked by the colonizing fungi Aspergillus 59\% and Penicillium 19\% of samples, respectively (Alvindia and Guzman 2016). Coffee bean samples studied by (Barcelo and Barcelo (2017) were found A. niger and A. ochraceus in $70 \%$ of samples when drying, $A$. ochraceus and A. niger in $31.3 \%$ of samples at a storage facility in the Philippines. Likewise, in the research results from Yani (2008) and Dharmaputra et al. (2019), it was found $A$. niger and A. ochraceus contamination on coffee beans in Indonesia (Bengkulu and South Sulawesi Provinces).

Generally, the coffee bean samples obtained from farmers were infected by fungi. The percentage of coffee beans infected by the types of fungi that have the potential to produce OTA, namely A. niger and A. ochraceus on tarpaulin drying and asphalt roads. Fungal diversity was found greater after drying coffee beans on tarpaulin, with 13 types of fungi, while on the asphalt road there were 10 types of fungi. These numbers were affected by high moisture content before storage that exceeds the SNI standards (National Standardization Agency of Indonesia 2017). To reduce the risk of contamination and increase quality, post-harvest handling methods used by farmers need to be improved, starting from the picking process through to drying methods.

\section{ACKNOWLEDGEMENTS}

This study was partly result of the dissertation research at Doctoral Program of Environmental Science, Graduate School, Sriwijaya University, Indonesia. The authors would like to thanks Prof. Rindit Pambayun for his help and support. The authors would like also to address their appreciation to the unanimous reviewer for their help and guidance.

\section{REFERENCES}

Alvindia DG, de Guzman MF, De. 2016. Survey of Philippine coffee beans for the presence of ochratoxigenic fungi, Mycotoxin Res 32: 61-67.

Barcelo JM, Barcelo RC. 2017. Post-harvest practices linked with ochratoxin A contamination of coffee in three provinces of Cordillera Administrative Region, Philippines. Food Addit Contam A 35 (2): 113.
Bradford KJ, Dahal P, Asbrouck JV, Kunusoth K, Bello P, Thompson, J, Wu F. 2018. The dry chain: Reducing post-harvest losses and improving food safety in humid climates. Trends Food Sci Technol 71: 84-93.

Bui-klimke TR, Wu F. 2015. Ochratoxin A and human health risk: A Review of the evidence. Crit Rev Food Sci Nutr 55 (13): 1860-1869.

Dharmaputra OK, Ambarwati S, Retnowati I, Nurfadila N. 2019. Fungal infection of stored Arabica coffee (Coffea arabica) beans in South Sulawesi Province, Indonesia. Biotropia 26 (2): 127-135.

Djossou O, Sevastianos R, Gaime I, Macarie H, Germain KT, Labrousse Y. 2015. Fungal population, including Ochratoxin A producing Aspergillus section Nigri strains from Ivory Coast coffee bean, Afr $\mathbf{J}$ Agric Res 10 (26): 2576-2589.

Duris D, Mburu JK, Durand N, Clarke R, Frank JM, Guyod B. 2010. Ochratoxin A contamination of coffee batches from Kenya in relation to cultivation methods and postharvest processing treatments. Food Addit Contam A 27 (6): 836-841.

Gautam AK, Bhadauria R. 2012. Characterization of Aspergillus species associated with commercially stored Triphala powder. Afr J Biotechnol 11 (104): 16814-16823.

Ghosh P and Venkatachalapathy N. 2014. Processing and Drying of Coffee-A Review. Intl J Eng Res Technol 3 (12): 785-794.

Houbraken J, Frisvad JC, Seifert KA, Overy DP, Tuthill, DM, Valdez JG, Samson RA. 2012. New penicillin-producing Penicillium species and an overview of section Chrysogena. Persoonia 29:78-100.

International Coffee Organization. 2019. Growing for prosperity Economic viability as the catalyst for a sustainable coffee sector. Coffee Development Report 2019-Overview. International Coffee Organization, London.

Leitao AL. 2019. Occurrence of Ochratoxin A in Coffee: Threads and Solutions-A Mini-Review. Beverage 5 (2): 36. DOI: 10.3390/beverages5020036.

Mehrotra RS. 1980. Plant Pathology. Tata Mc.Graw Hill Publishing Company Limited. India.

National Standardization Agency of Indonesia. 2017. Overview of Indonesian National Standards: Coffee beans; Cocoa beans and Seaweed. National Standardization Agency of Indonesia, Jakarta.

Neto DPC, Pereira GVM, Tanobe VOA, Soccol VT, Silva BJG, Rodrigues C, Soccol CR. 2017. Yeast diversity and physicochemical characteristics associated with coffee bean fermentation from the Brazilian Cerrado Mineiro Region. Fermentation 3 (11): 1-11

Nganou ND, Durand N, Tatsadjieu NL, Métayer I, Montet D, Mbofung CMF. 2014. Fungal flora and ochratoxin A associated with coffee in Cameroon. Br Microbiol Res J 4 (1): 1-17.

Noonim P, Mahakarnchanakul W, Nielsen KF, Frisvad JC, Samson RA. 2008. Isolation, identification and toxigenic potential of ochratoxin Aproducing Aspergillus species from coffee beans grown in two regions of Thailand. Intl J Food Microbiol 128 (2): 197-202.

Noonim P, Mahakarnchanakul W, Varga J, Frisvad JC, Samson, RA. 2008. Two novel species of Aspergillus section Nigri from Thai coffee beans. Int J Syst Evol Microbiol 58 (7): 1727-1734.

Rezende EF, Borges JG, Cirillo MÂ, Prado G, Paiva LC, Batista LR. 2013. Ochratoxigenic fungi associated with green coffee beans (Coffea arabica L.) in conventional and organic cultivation in Brazil. Brazilian J Microbiol 44 (2): 377-384.

Samson RA, Hoekstra, ES, Frisvad JC. Introduction to Food and Airborne Fungi, 7th eds., Centraalbureau voor Schimmelcultures, Utrecht, Netherlands.

Samson RA, Visagie CM, Houbraken J, Hong SB, Vubka V, Klaassen CH, Perrone G, Seifert KA, Susca A, Tanney JB, Varga, J, Kocsube S, Szigeni G, Yaguchi T, Frisvard JC. 2014. Phylogeny, identification and nomenclature of the genus Aspergillus. Stud Mycol 78:141-73.

Taniwaki MH, Pitt JI, Copetti MV, Teixeira AA, Iamanaka BT. 2019. Understanding mycotoxin contamination across the food chain in Brazil : Challenges and opportunities. Toxins 11 (411): 1-17.

Varga J, Frisvad S, Kocsubé S, Brankovics B, Tóth B, Szigeti G, Samson A. 2011. New and revisited species in Aspergillus section Nigri. Stud Mycol 69 (1): 1-17.

Yani A. 2008. Fungal Infection at Coffee Beans during Primary Processing (Case Study in Bengkulu Province). Jurnal Akta Agrosia 11 (1): 87-95. [Indonesian] 